\title{
KUALITAS FISIK DAGING BROILER DI PASAR MODERN KOTA BANDAR LAMPUNG
}

\author{
Physical Quality of Broiler Meat in Modern Markets of Bandar Lampung City \\ Akhmad Rangga, Khaira Nova, Riyanti \\ Department of Animal Husbandry, Faculty of Agriculture Lampung University \\ Soemantri Brojonegoro No.1 Gedong Meneng Bandar Lampung 35145 \\ e-mail : akhmadrangga94@gmail.com
}

\begin{abstract}
This study aimed to determine the physical quality of broiler meat including $\mathrm{pH}$ value, water holding capacity, and cooking losses in the modern market of Bandar Lampung City. This research was conducted on Januari-March 2020. The research material was breast fillet meat. Samples came from six modern markets in the city of Bandar Lampung (Mall Boemi Kedaton, Transmart, Central Plaza, Chandra Teluk, Chandra Karang, and Mall Kartini). The variables observed in this study were the degree of acidity ( $\mathrm{pH})$, water holding capacity (DIA), and cooking losses. The results of this study indicated that the degree of acidity $(\mathrm{pH})$ in the modern market of Bandar Lampung City ranged from 6,109-6,386. The DIA value in the modern city market Bandar Lampung ranges from $61,157-68,021 \%$, the value of cooking losses in the modern market of Bandar Lampung City ranges from 30,032-39,494\%. The results of this study indicate that the $\mathrm{pH}$, DIA, and cooking losses have met the standards for consumption in the six modern markets in the city of Bandar Lampung.
\end{abstract}

Keywords: Broiler, Modern market, Degree of acidity (pH), Water holding capacity (DIA), Cooking losses.

\begin{abstract}
ABSTRAK
Penelitian ini bertujuan untuk mengetahui kualitas fisik daging broiler meliputi nilai $\mathrm{pH}$, daya ikat air, dan susut masak di pasar modern Kota Bandar Lampung. Penelitian ini dilaksanakan pada Januari-Maret 2020. Materi penelitian berupa daging fillet broiler bagian dada. Sampel berasal dari enam pasar modern di Kota Bandar Lampung (Mall Boemi Kedaton, Transmart, Central Plaza, Chandra Teluk, Chandra Karang, dan Mall Kartini). Variabel yang diamati pada penelitian ini meliputi derajat keasamaan (pH), daya ikat air (DIA), dan susut masak. Hasil penelitian ini menunjukkan bahwa derajat keasamaan ( $\mathrm{pH}$ ) di pasar modern Kota Bandar Lampung berkisar 6,109-6,386. Nilai DIA di pasar modern Kota Bandar Lampung berkisar 61,157-68,021\%, nilai susut masak di pasar modern Kota Bandar Lampung berkisar 30,032-39,494\%. Hasil penelitian ini menunjukkan bahwa dilihat nilai pH, DIA, dan susut masak telah memenuhi standar layak konsumsi di keenam pasar modern di Kota Bandar Lampung.
\end{abstract}

Kata kunci: Broiler, Daya ikat air (DIA), Derajat keasaman (pH), Pasar modern, Susut masak

\section{PENDAHULUAN}

Daging broiler adalah bahan makanan yang mengandung nilai gizi yang tinggi sehingga banyak digemari oleh semua kalangan masyarakat di Indonesia. Tingginya kandungan nilai gizi pada daging broiler menyebabkan karkas broiler lebih mudah mengalami penurunan kualitas dan rentan terkontaminasi oleh mikroorganisme bila tidak dilakukan penanganan yang tepat setelah pemotongan. Penurunan kualitas yang terjadi pada daging broiler setelah pemotongan diantaranya penurunan kualitas fisik dan kimia. Hal ini disebabkan oleh berhentinya sirkulasi darah setelah ternak dipotong dan berhentinya fungsi darah sebagai pembawa oksigen sehingga proses respirasi berhenti dan berlangsung proses glikolisis anaerob

Uji kualitas daging fisik broiler dapat diketahui melalui berbagai pengujian seperti uji daya ikat air, uji derajat keasamaan $(\mathrm{pH})$, dan susut masak daging broiler. Kapasitas mengikat air adalah kemampuan daging untuk mengikat dan menahan selama daging mendapat tekanan dari luar, seperti pemotongan, pemanasan, penggilingan, atau pengepresan. Daging dengan kapasitas mengikat air yang rendah akan menyebabkan kehilangan cairan yang banyak. Hal ini mempengaruhi keadaan kualitas fisik pada daging seperti, perubahan warna, tekstur, 
keempukan, juiceness, serta pengerutan daging. Hal ini mempengaruhi keadaan kualitas fisik pada daging seperti perubahan warna, tekstur, keempukan, juicennes, serta pengerutan daging.

\section{MATERI DAN METODE}

Penelitian ini dilaksanakan pada 7 Januari-Maret 2020. Penelitian dilakukan di pasar-pasar modern Kota Bandar Lampung yang menjual filet daging broiler meliputi Mall Boemi Kedaton, Transmart, Central Plaza, Chandra Teluk, Chandra Karang, dan Mall Kartini.

\section{Materi}

Bahan yang digunakan pada penelitian ini adalah daging broiler yang berasal dari beberapa pasar modern di Kota Bandar Lampung. Daging broiler yang digunakan adalah daging broiler bagian dada yang sudah dilakukan pengemasan tanpa memperhatikan umur dan bangsa broiler. Peralatan yang digunakan pada penelitian ini adalah pisau, timbangan analitik, mortil, talenan, $\mathrm{pH}$ meter, label, wadah plastik, panci yang digunakan untuk merebus air, kompor, cawan porselen, besi pemberat $(10 \mathrm{~kg})$, kaca plat ukuran $25 \times 25 \mathrm{~cm}$, kertas saring ukuran $5 \times 5 \mathrm{~cm}$, Beaker glass, termometer, kamera, dan alat tulis.

\section{Metode \\ Rancangan Percobaan}

Penelitian ini menggunakan metode survei dan pengambilan sampel menggunakan metode Slovin dan penentuan sampel menggunakan rumus Mustafa (2010) :

Keterangan :

$$
n=\frac{\mathrm{N}}{1+\left(\mathrm{N} \times \mathrm{e}^{2}\right)}
$$

$\mathrm{n}=$ jumlah minimal sampel

$\mathrm{N}=$ jumlah populasi (ayam yang dijual/hari)

$\mathrm{e}=$ tingkat kesalahan dalam memilih anggota sampel yang ditolerir sebesar $10 \%$

\section{Peubah yang Diamati}

Peubah yang diamati pada penelitian ini adalah derajat keasaman $(\mathrm{pH})$, daya ikat air, dan susut masak.

\section{HASIL DAN PEMBAHASAN}

\section{Derajat Keasaman (pH)}

Pada penelitian ini didapat hasil rata-rata nilai $\mathrm{pH}$ daging dada broiler di pasar modern Kota Bandar Lampung pada Tabel 1. Hasil penelitian ini menunjukkan bahwa daging dada broiler yang diperoleh dari pasar modern di Kota Bandar Lampung yaitu di pasar modern Chandra Teluk memiliki nilai $\mathrm{pH}$ 6,386, di Chandra MBK 6,299, di Carrefour Transmart 6,109, di Chandra Teluk 6,368, di Super Indo Mall Kartini 6,170, dan di Hypemart Central Plaza 6,223. Nilai $\mathrm{pH}$ dari masing-masing pasar bervariasi dan berbeda sedikit, namun masih pada $\mathrm{pH}$ normal daging ayam.

Tabel 1. Rata-rata $\mathrm{pH}$ daging dada broiler di

\begin{tabular}{ccc}
\multicolumn{3}{c}{ pasar modern Kota Bandar Lampung } \\
\hline \multirow{2}{*}{ No. } & Nama Pasar & $\begin{array}{c}\mathrm{pH} \text { (Derajat } \\
\text { Keasamaan) }\end{array}$ \\
\hline 1 & Chandra Karang & 6,186 \\
2 & Chandra MBK & 6,299 \\
3 & CarrefourTrans Mart & 6,109 \\
4 & Chandra Teluk & 6,368 \\
& Super Indo Mall & 6,170 \\
5 & Kartini & 6,223 \\
& Hypemart Centra \\
\hline
\end{tabular}

Derajat keasamaan atau $\mathrm{pH}$ yang diperoleh dari hasil penelitian ini sama dengan kondisi $\mathrm{pH}$ daging ayam segar tanpa diberi perlakuan berkisar 6,00-6,37 yang dilaporkan oleh Hajrawati et al. (2016). Hal ini sesuai dengan pendapat Suradi (2008) yang menunjukkan bahwa daging ayam broiler memiliki $\mathrm{pH}$ 6,31 pada saat segera setelah pemotongan. Perbedaan nilai $\mathrm{pH}$ pada Tabel 1 antara pasar modern Chandra Teluk dan pasar modern Trans Mart disebabkan oleh lama penyimpanan ternak setelah dilakukan pemotongan.

Adanya perbedaan $\mathrm{pH}$ pada daging broiler disebabkan oleh kadar glikogen dalam jaringan otot, yang berimbas pada penimbunan asam laktat dalam daging. Hal tersebut disebabkan oleh ketersediaan asam laktat di dalam otot. Ketersediaan asam laktat ini dipengaruhi oleh kandungan glikogen. Kandungan glikogen otot sangat rendah yaitu pada kisaran 0,5-1,3\% dari berat daging segar (Soeparno, 1992) sehingga penurunan $\mathrm{pH}$ daging terjadi secara bertahap dan membutuhkan jangka waktu yang sama. Upaya yang dapat dilakukan untuk mempertahankan $\mathrm{pH}$ dan menghindari kontaminasi dari mikroorganisme yang terdapat di lingkungan sekitar adalah memberikan perlakuan daging dengan menempatkan di suhu minimal $-4^{\circ} \mathrm{C}$. Penggunaan suhu tersebut dapat menghambat pertumbuhan mikroorganisme karena suhu dingin akan menurunkan energi kinetik. Energi kinetik menjadikan serat daging melebar karena gaya elektrostatis menyebabkan miofibril dapat terus melebar dan rusak sehingga menurunkan kecepatan reaksi kimia termasuk aktivitas metabolisme mikroorganisme (Xiong dan Kupski, 1999). Oleh sebab itu penggunaan 
suhu dingin sangat dianjurkan agar menurunkan aktivitas mikroorganisme dan memperpanjang masa simpang daging broiler.

\section{Daya Ikat Air (DIA)}

Rata-rata nilai DIA dari enam pasar modern di Kota Bandar Lampung berdasarkan hasil penelitian (Tabel 2) diperoleh data yaitu di pasar modern Chandra Karang yaitu $61,157 \%$, di Chandra MBK 65,531\%, di Carrefour Trans Mart $68,021 \%$, di Chandra Teluk 62,002\%, di Super Indo Mall Kartini 63,840\% dan di Hypemart Central Plaza 62,216\%.

Tabel 2. Rata-rata nilai daya ikat air (DIA) daging dada broiler di pasar modern Kota Bandar Lampung

\begin{tabular}{ccc}
\hline No. & Nama Pasar & $\begin{array}{r}\text { Daya Ikat Air } \\
\text { (DIA) }\end{array}$ \\
\hline 1 & Chandra Karang & 61,157 \\
2 & Chandra MBK & 65,531 \\
& Carrefour Trans & 68,021 \\
3 & Mart & 62,002 \\
4 & Chandra Teluk & 63,840 \\
5 & Super Indo Mall & Kartini \\
6 & Hypemart Central & 62,216 \\
\hline
\end{tabular}

Tinggi dan rendahnya nilai DIA dipengaruhi oleh $\mathrm{pH}$, bangsa, pembentukan aktomiosin (rigor mortis), temperatur, pelayuan karkas, tipe daging, lokasi otot, fungsi otot, umur, pakan, dan lemak intramuskuler. Salah satu faktor yang mempengaruhi tinggi rendahnya DIA adalah pengaruh $\mathrm{pH}$. Jika $\mathrm{pH}$ berada pada $\mathrm{pH}$ isoeletrik protein daging, sejumlah muatan positif dibebaskan dan terdapat surplus muatan negatif yang mengakibatkan penolakan miofilamen dan memberi lebih banyak ruang untuk molekul air.

Dengan demikian jika $\mathrm{pH}$ daging di atas titik isoelektik protein-protein daging maka DIA akan meningkat. Pernyataan ini selaras dengan pendapat Lawrie (2003), apabila nilai pH lebih tinggi atau lebih rendah dari titik isoelektrik daging $(5,0-5,1)$ maka nilai daya ikat air akan tinggi atau nilai $\mathrm{MgH}_{2} \mathrm{O}$ rendah. Pada penelitian ini rata-rata nilai $\mathrm{pH}$ dari enam pasar modern di Kota Bandar Lampung pada Tabel 1 diperoleh nilai lebih tinggi dari $\mathrm{pH}$ isolektrik yaitu sebesar $5,0-5,7$, sehingga mengakibatkan daya ikat air dari enam pasar modern tersebut tinggi.

Keadaan nilai $\mathrm{pH}$ tersebut masih keadaan belum asam, sehingga tidak mempengaruhi daya ikat air pada daging tersebut.
Pernyataan di atas sesuai dengan pendapat Kadarsih (2004), antara nilai pH ultimat dengan daya ikat air terdapat hubungan yang erat. Daging yang memiliki $\mathrm{pH}$ rendah dengan banyaknya asam laktat akan kekurangan gugus reaktif protein dan menyebabkan makin banyaknya air daging yang lepas sehingga menurunkan DIA daging. Daging dengan nilai $\mathrm{pH}$ yang rendah, cenderung memiliki nilai DIA yang rendah juga. Perbedaan pada keenam pasar modern di Kota Bandar Lampung tersebut diduga disebabkan oleh faktor lain yang mempengaruhi DIA, diantaranya otot, pakan, transportasi, temperatur, kelembaban, penyimpanan dan preservasi, jenis kelamin, kesehatan, dan perlakuan sebelum pemotongan (Soeparno, 2009).

Nilai DIA yang diperoleh dari penelitian ini lebih tinggi dari pernyataan Soeparno (2009) bahwa daya ikat air daging broiler sekitar 20$60 \%$. Nilai DIA yang lebih tinggi pada penelitian ini disebabkan oleh penanganan daging setelah dilakukan pemotongan seperti seleksi karkas, Cold boning, dan pemilihan daging. Dapat diketahui dari penjelasan tersebut bahwa semakin rendah daya ikat air pada daging membuat kualitas daging akan rendah. Hal ini dikarenakan banyaknya cairan dari daging yang keluar menyebabkan penurunan berat daging, berkurangnya kelezatan dan berkurangnya nilai gizi (Nurwanto et al., 2003). Keadaan daging yang beku sebelum dilakukan pemasakan menyebabkan daging harus dilakukan pencairan (thawing) terlebih dahulu sebelum diberi perlakuan.

\section{Susut Masak}

Susut masak adalah berat yang hilang selama pemasakan, makin tinggi suhu pemasakan semakin tinggi susut masak pada daging broiler. Kualitas daging dikatakan baik apabila memiliki nilai susut masak yang rendah.

Tabel 3. Nilai susut masak daging dada broiler di pasar modern Kota Bandar Lampung

\begin{tabular}{ccc}
\hline No. & Nama Pasar & $\begin{array}{c}\text { Susut } \\
\text { Masak }\end{array}$ \\
\hline 1 & Chandra Karang & 33,072 \\
2 & Chandra MBK & 30,178 \\
3 & Carrefour Trans Mart & 39,494 \\
4 & Chandra Teluk & 30,332 \\
5 & Super Indo Mall Kartini & 30,032 \\
6 & Hypemart Central Plaza & 33,060 \\
\hline
\end{tabular}


Pada penelitian ini (Tabel 3) diperoleh hasil susut masak pasar Chandra Karang yaitu $33,072 \%$, di Chandra MBK 30,072\%, di Carrefour Transmart 39,494\%, di Chandra Teluk 30,332\%, di Super Indo Mall Kartini 30,032\% dan di Hypemart Central Plaza 33,060\%. Nilai susut masak yang diperoleh dari hasil penelitian ini masih dalam keadaan baik, nilai susut masak yang diperoleh tidak berbeda jauh dengan hasil penelitian Jaelani et al.(2014) dimana kisaran rata-rata susut masak selama penelitian adalah $30,61-38,23 \%$.

Pada penelitian ini terdapat tiga pasar modern yaitu pasar Chandra MBK sebesar 30,178\%, pasar Chandra Teluk sebesar 30,332\% dan pasar Super Indo Mall Kartini sebesar $30,032 \%$ yang memiliki nilai susut masak hampir sama dan hanya berbeda sedikit. Nilai susut masak pada tiga pasar tersebut lebih kecil dibandingkan penelitian Sundari et al. (2015) bahwa pada broiler memiliki susut masak yang berkisar antara $32,00-34,20 \%$. Nilai pada tiga pasar tersebut dikatakan lebih baik karena memiliki nilai susut masak yang rendah. Hal ini sesuai dengan pendapat Suradi (2008) bahwa daging dengan nilai susut masak yang rendah dibawah 35\% memiliki kualitas yang baik karena kemungkinan keluarnya nutrisi daging selama pemasakan juga rendah. Daging dengan susut masak yang rendah mempunyai kualitas fisik yang relatif lebih baik daripada daging dengan susut masak yang besar, karena kehilangan nutrisi selama pemasakan. Hal ini berlaku untuk pasar modern Chandra Karang dengan nilai susut masak sebesar 33,072\% dan Hypemart Central Plaza dengan sebesar 33,060\%, karena memiliki nilai susut masak dibawah $35 \%$. Nilai susut masak dari keenam pasar modern di Kota Bandar Lampung berbanding lurus dengan $\mathrm{pH}$ yang dimiliki setiap pasar (Tabel 1) karena rataan $\mathrm{pH}$ yang diperoleh dari penelitian ini masih berada di atas $\mathrm{pH}$ isoelektrik. Pernyataan diatas selaras dengan pendapat Soeparno (2005) bahwa nilai susut masak sangat dipengaruhi oleh nilai $\mathrm{pH}$ daging. Apabila nilai $\mathrm{pH}$ isoelektrik $(5,0-5,1)$ lebih tinggi atau lebih rendah, maka nilai susut masak daging tersebut akan rendah.

\section{SIMPULAN}

\section{Simpulan}

Berdasarkan penelitian yang telah dilakukan dapat disimpulkan bahwa:

1. Kualitas daging dada broiler yang diperoleh dari pasar modern di Kota Bandar Lampung yaitu nilai $\mathrm{pH}$ tertinggi terdapat di pasar modern Chandra Teluk sebesar 6,386 dan nilai
$\mathrm{pH}$ terendah terdapat di Trans Mart sebesar 6,109 .

2. Kualitas daging dada broiler yang diperoleh dari pasar modern di Kota Bandar Lampung yaitu nilai daya ikat air (DIA) tertinggi di pasar modern Trans Mart 68,021\% dan nilai terendah di pasar modern Chandra Teluk $61,157 \%$.

3. Kualitas daging dada broiler yang diperoleh dari pasar modern di Kota Bandar Lampung yaitu nilai susut masak tertinggi pada pasar modern Trans Mart 39,494\% dan nilai terendah di Mall Kartini 30,032\%. Rendahnya nilai susut masak relatif lebih baik karena kandungan nutrisi yang terdapat pada daging masih banyak.

\section{DAFTAR PUSTAKA}

Hajrawati, M. Fadliah, Wahyuni, II. Arief, 2016, Kualitas Fisik, Mikrobiologis dan Organoleptik Daging Ayam Broiler pada Pasar Tradisional di Bogor. J. Ilmu Produksi dan Teknologi Hasil Peternakan 4 (3): 386-389.

Jaelani, A., S. Dharmawati dan Wanda, 2014. Berbagai Lama Penyimpanan Daging Ayam Broiler Segar dalam Kemasan Plastik pada Lemari Es (Suhu $4^{\circ} \mathrm{C}$ ) dan Pengaruhnya terhadap Sifat Fisik dan Organoleptik. Zirra'ah. 39 (3): 119-128.

Kadarsih, S., 2004. Performans Sapi Bali Berdasarkan Ketinggian Tempat di Daerah Transmigrasi Bengkulu: I Performans Pertumbuhan. J. Ilmu-Ilmu Pertanian, 6(1): 50-56.

Lawrie, R.A. 2003. Ilmu Daging. Edisi Kelima. Universitas Indonesia Press, Jakarta.

Nurwanto, Septianingrum, Surhatayi, 2003. Buku Ajar Dasar Teknologi Hasil Ternak, Universitas Diponegoro. Semarang.

Soeparno, 1992, Pengaruh Lama Pemasakan dan Macam Otot terhadap $\mathrm{pH}$, Water Holding Capacity, Cooking Loos, dan Keempukan Daging. Laporan Penelitian No. UGM/PT/2895/01/39. Fakultas Peternakan Universitas Gadjah Mada. Yogyakarta.

Soeparno, 2009, Ilmu dan Teknologi Daging, Cetakan Kelima, Gadjah Mada University Press. Yogyakarta.

Soeparno, 2015, Ilmu dan Teknologi Daging, Cetakan ke 6 (Edisi Revisi), Gadjah Mada University Press, Yogyakarta.

Suradi, K., 2008. Perubahan Sifat Fisik Daging Ayam Broiler Post Mortem Selama Penyimpanan Temperatur Ruang, Tesis, 
Fakultas Peternakan. Universitas Padjajaran. Bandung.

Sundari, K.Bayu, C.Wariyah, 2015, Pengaruh Penambahan Nanopartikel Ekstrak Kunyit Sediaan Serbuk dalam Ransum terhadap Kualitas Fisik Daging Ayam Broiler Umur 5 Minggu. J. AgriSains. 6(1).

Xiong, Y.L. and D. R. Kupski, 1999, Time Dependent Marinade Absorption and Retention, Cooking Yield, and Palatability of Chicken Filets Marinated in Various Phospate Solution. Poultry Science. 78: 1053-1059 